\title{
トランシップ内生化による港湾間輸送モデルの 組み合わせ要素の削減に関する研究
}

\author{
外井哲志 \\ 正会員 工博 九州大学助教授 大学院工学研究院 (广812-8581 福岡市東区箱崎 6-10-1) \\ E-mail : toi@doc.kyushu-u.ac.jp
}

\begin{abstract}
本研究の輸送モデルは，複数の港湾間でコンテナ貨物を輸送する場合に，荷役費用を含んだ輸送費用が最 小になる最適輸送パターンを線形計画法に基づいて求めるものであり，施設整備の前後の条件を入力データ としてそれぞれの最適輸送パターンを計算し，輸送費用の変化を施設整備の効果としてとらえることが可能 であるが，適用ケースの規模が大きくなった場合，貨物船の経路および貨物船間のトランシップの組み合わ せが増大し, 総組み合わせケースが膨大となるため, 実質的に計算が不可能となる. そこで, 本研究では, 貨物船間のトランシップの組み合わせを内生化する変数と制約条件を導入して，それらの変数が最適化計算 の過程で決定される数学モデルの定式化を試み, これに伴う計算量の削減効果について検討したものである.
\end{abstract}

Key Words : linear programming, transportation problem, container, port planning

\section{1. 研究目的}

本研究は, 特定港湾における荷役システムの導入 や大水深岸壁整備に基づく港湾機能の向上が，その 港湾を取り巻くコンテナ貨物輸送の構造に与える影 響について分析することを目的とした一連の研究の 一部である.

関連する研究として次のような研究がある.

まず，コンテナ貨物の港湾間輸送を取り扱った研 究として, 福地 ${ }^{1)}$ は, リニア駆動搬送台車を用いた 高密度集積コンテナストックヤードの概念設計を行 い,リニア駆動のコンテナ搬送システムの有効性を 示した.

また，ゲーム論的な考え方に基づく研究として， 黒田ら ${ }^{2)}$ は，荷主と船社のゲーム的関係から国内コ ンテナ貨物の流動分析を行っている. 藤野ら ${ }^{3)}$ は, 国際コンテナ航路の港湾別寄港頻度の予測を行って, 荷主と船社の非協力ゲーム理論を用いている. 著者 ら ${ }^{4)}$ は, 特定港湾の施設整備による港湾機能の向上 が港湾ネットワーク全体に与える影響について, 荷 主と船社の非協力ゲームに基づく港湾選択行動モデ ルを作成し, 貨物取扱量や輸送コストの変化を算出 した.

家田ら ${ }^{5)}$ は, アジア圈の代表的な港湾を対象とし て,港湾内・港湾間の貨物流動をネットワーク配分問 題としてモデル化している.
これらに対し，著者ら ${ }^{6)}$ は，港湾ネットワーク全 体の輸送コストが最小となるようにコンテナ輸送が 行われると仮定し (システム最適化), ある特定港湾 の機能向上がネットワーク全体に与える影響につい て分析することを目的とした港湾間輸送モデルを開 発した. また，港湾におけるコンテナのトランシッ プと港湾の係留容量（水深も含む）が相互に深く関 わっていることに着目し，これを個々の港湾レベル でミクロに表現するため，スケジュール制約を導入 し，線形関数のみでトランシップを扱えるよう定式 化を工夫した. さらに, 需要を OD ではなく発生集 中のみで与え, コンテナ流動, 航路の自由度を与え た点など，他の研究にはみられない特徴である.

以下，このモデルを『基本モデル』と呼ぶことに する. 基本モデルはシステム最適化の立場を取って おり, 所与の輸送条件に対して得られる輸送費用は, 現実のいかなる輸送パターンよりも小さい. すなわ ち，システム最適化によって施設が最も効率的に利 用された場合の輸送費用は，最低限必要な輸送費用 であるとみなせることから，本研究では，施設整備 によるその変化を施設整備の純粋な効果と考え, こ れを分析対象としようとするものである.

さらに，基本モデルを用いることにより，輸送の 最適化の過程で生じるコンテナ貨物の積替えの発生 量から，施設整備と港湾のハブ機能の関係について も考察を加え，八ブ港湾の実現を可能にするための 
施設整備の質と規模について分析することもできる. しかし, 基本モデルでは, 港湾数・貨物船数が大 きくなった場合, 貨物船の経路の組み合わせ, およ び貨物船間のトランシップの組み合わせが増大し, その結果として組み合わせ総数が膨大になるため, 実質的に計算が不可能になるという欠点があった.

そこで, 本研究では, 上記 2 つ組み合わせ要素 のうち, 貨物船間のトランシップの組み合わせに着 目し，これを条件として外生的に与えるのではなく， 内生的に取扱うための変数と制約条件を導入するこ とによって, 組み合わせ総数の削減を図ろうとする ものである. このため, それらの変数が最適化計算 の過程で決定されるような数学モデルの定式化を試 みるとともに, 計算量に関する改良の効果について 述べる.

\section{2. 港湾間輸送モデルの基本型}

\section{(1) 基本モデルの概要 ${ }^{6)}$}

本モデルは, 港湾配置, 港湾規模（水深別バース 数）と荷役速度, 港湾での使用料金, 貨物船の数と 規模, 各港湾での輸出量, 輸入量を既知量としたう えで, 各港での各貨物船の積降ろし量, 貨物船相互 のトランシップ量, 各貨物船の出港時刻を変数とし て求める. 本モデルは, 港湾の規模, 荷役速度, 料 金等を政策変数とし，これらを変化させつつ，最小 輸送費用の変化を分析するといった使い方ができる.

計算は，(1)輸送経路とトランシップの設定，(2)線 形計画法による計算のための入力データの作成, (3) 線形計画法による最適解の計算, (4)港湾容量のチェ ック，の手順で実行するが，(2)〜(4)は(1)で設定した 輸送パターンごとに行う.

本モデルでは，図ー1に示すように船積 $\rightarrow$ 運航 $\rightarrow$ 入港待ち $\rightarrow$ 陸揚の一行程を貨物船 $\mathrm{s}$ の第 $\mathrm{r}$ 番目の航 路便 $(\mathrm{s}, \mathrm{r})$ と表し，これを単位とした変数の設定を行 った. なお，r=e は一定期間内における貨物船 $\mathrm{s} の$ 最終航路便を表す.

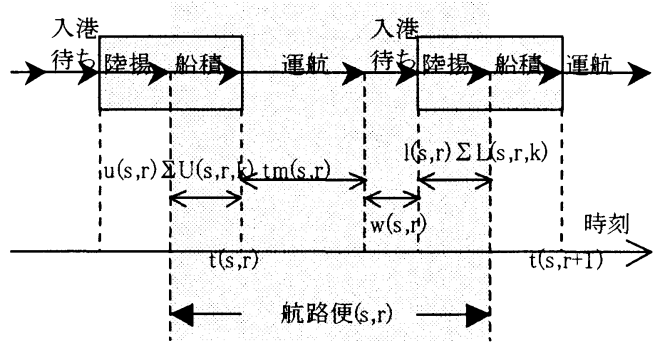

図一1 航路便と変数の定義
(2)輸送経路, トランシップの組み合わせ数

入力データの貨物船の大きさと港湾の岸壁水深を 考慮して, 寄港可能な港湾の中から最大寄港数の範 囲内で，いくつかを経由する経路を全て列挙する. ここで, 貨物船 $\mathrm{s}(1 \leqq \mathrm{~s} \leqq \mathrm{~S})$ の経路数を $\mathrm{r}(\mathrm{s})$ とすると， 経路組み合わせ総数は, $\mathrm{M}=\mathrm{r}(1) \times \mathrm{r}(2) \times \cdots \times \mathrm{r}(\mathrm{S})$ 通りである。

ある貨物船の航路便の目的港が，他貨物船の航路 便の出発港となっている場合, この 2 つの航路便間 でトランシップ輸送が可能である. ある経路組み合 わせ $(\mathrm{m})$ の全体でトランシップ輸送可能な航路便の 組み合わせ数が $\mathrm{k}(\mathrm{m})$ である場合, トランシップ輸送 を全く行わない場合から全てを行う場合まで含める と, トランシップ組み合わせ総数は $2^{\mathrm{k}(\mathrm{m})}$ 通りとなる. したがって, 計算ケースの総数は $\sum_{m=1, M} 2^{k(m)}$ となる.

\section{(3)線形計画モデル}

\section{a)目的関数}

目的関数はコンテナ輸送に関わる総費用であり, これを最小化する以下の式で表す.

式(1)において, 第 1 項は貨物船の総運航費用と入 港料, 第 2 項は港湾での荷役費用, 第 3 項は貨物船 乗組員の賃金および減価償却費等の船費である.

$$
\begin{aligned}
& \text { Minimize } \\
& \begin{array}{l}
Z=\sum_{s} \sum_{r}\{\operatorname{Dis}(o(s, r), d(s, r)) \cdot \text { Fuel }(s)+f p(d(s, r))\} \\
+\sum_{s} \sum_{r}\left\{f(s, r) \cdot \sum_{\mathrm{k}} L(s, r, k)+g(s, r) \cdot \sum U(s, r, k)\right. \\
\left.+g(s, r) \cdot \sum_{\sigma\left(s r, s^{\prime} r^{\prime}\right)=1} \sum_{k} T R k\left(s r, s^{\prime} r^{\prime}\right)\right\} \\
+\sum_{s}\left\{t(s, e)+t m(s, e)+w(s, e)+u(s, e) \cdot \sum_{k} U(s, e, k)\right. \\
\left.+u(s, e) \sum_{\sigma\left(s e, s^{\prime} r^{\prime}\right)=1} \sum_{k} T R k\left(s e, s^{\prime} r^{\prime}\right)\right\} \cdot b(s)
\end{array}
\end{aligned}
$$

ここに,

Dis $(i, j):$ 港湾 $\mathrm{i}$ と港湾 $\mathrm{j}$ 間の海上距離 $(\mathrm{km})$,

$o(s, r), d(s, r)$ : それぞれ航路便 $(\mathrm{s}, \mathrm{r})$ の出発港, 目的 港,

$f p(d(s, r)):(\mathrm{s}, \mathrm{r})$ の目的港における入港料等,

Fuel(s)，b(s): それぞれ貨物船 $\mathrm{s}$ の燃料費(円 $/ \mathrm{km})$, 船費(円/時間),

$t(s, r), \operatorname{tm}(s, r), w(s, r):$ それぞれ航路便 $(\mathrm{s}, \mathrm{r})$ の出発 時刻, 運航時間(時間), 入港待ち時間(時間),

$f(s, r), g(s, r)$ : それぞれ航路便 $(\mathrm{s}, \mathrm{r})$ の出発港, 目的港 での 1TEU 当たり荷役費用(円/TEU),

$I(s, r), u(s, r):$ それぞれ航路便 $(\mathrm{s}, \mathrm{r})$ の出発港, 目的港 での 1TEU 当たりの荷役時間(時間/TEU), 
$L(s, r, k), U(s, r, k)$ : それぞれ航路便 $(\mathrm{s}, \mathrm{r})$ の品目 $\mathrm{k}$ の 船積み量と陸揚げ量(TEU),

$T R_{k}\left(s r, s^{\prime} r^{\prime}\right)$ : 航路便 $(\mathrm{s}, \mathrm{r})$ から航路便 $\left(\mathrm{s}^{\prime}, \mathrm{r}^{\prime}\right)$ 一の品目 $\mathrm{k}$ に関するトランシップ貨物量,

$\sigma\left(s r, s^{\prime} r^{\prime}\right)$ : 航路便 $(\mathrm{s}, \mathrm{r})$ と航路便 $\left(\mathrm{s}^{\prime}, \mathrm{r}^{\prime}\right)$ の間でトランシ ップ輸送を行う場合は 1 , 行わない場合は 0 .

なお, (s,e)は貨物船 $\mathrm{s}$ の最終航路便を表しており, 式(1)の第 3 項の \{ \} 内は最終航路便で目的港に到 着し荷役を終える時刻である. 本モデルでは, 計算 開始時刻 $\mathrm{t}=0$ を輸送開始時刻としているので，式(3) の\{\}内は貨物船 $\mathrm{s}$ の総稼㗢時間を意味しており， これに船費 $\mathrm{b}(\mathrm{s})$ を乗じて運航費用を求めたものであ る.

\section{b)制約条件}

図ー2 に港湾内コンテナ貨物流動の一例を示す. この図では, 貨物船 3 は港湾の実輸出入コンテナの 積み降ろしを行い, 貨物船 $1 ， 2 ， 4$ は実輸入の陸揚 げとともに，貨物船 4 から 1 と 2 へのトランシップ を行っている様子を示している.

図一2のようにコンテナ輸送種類別に変数を作る と, 制約条件には，以下(1) (6)の制約条件が考えら れ，これらの制約条件式は線形式で表現できる.

\section{(1)実輸送に関する条件}

各港の輸出量（輸入量）は，その港湾を出港（入 港)する貨物船の実輸出船積み量の総和で表される.

$$
\left.\begin{array}{ll}
\sum_{o(s, r)=i} L(s, r, k)=S i k & (\text { for all } i, k) \\
\sum_{d(s, r)=i} U(s, r, k)=D i k & (\text { for all } i, k) \\
こ こ に, &
\end{array}\right\}
$$

Sik, Dik: それぞれ港湾 $\mathrm{i}$ 品目 $\mathrm{k}$ の輸出量, 輸入量.

(2)港湾におけるトランシップ貨物に関する条件

各港湾において，トランシップ船積み量の総和と トランシップ陸揚げ量の総和は等しい.

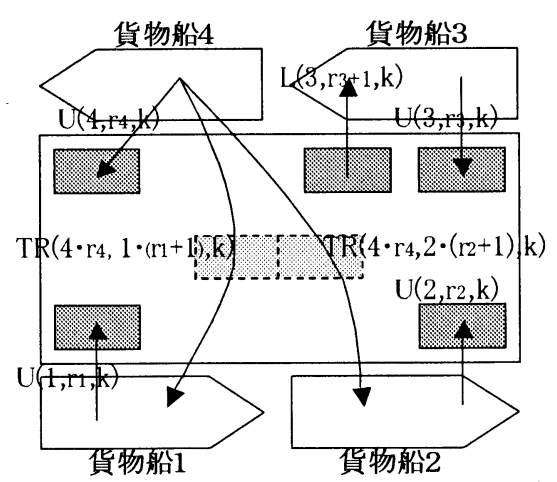

図一2 港湾内コンテナ貨物流動 $\sum_{o(s, r)=i} \sum_{k} T R_{k}\left(s^{\prime} r^{\prime}, s r\right)=\sum_{d\left(s^{\prime} r^{\prime}\right)=i} \sum_{k} T R_{k}\left(s^{\prime} r^{\prime}, s r\right)$

(3)品目別の積載量と輸送量に関する条件

航路便 $(\mathrm{s}, \mathrm{r})$ の積載量は, $\mathrm{r} \neq 1, \mathrm{e}$ の場合, 航路便 ( $\mathrm{s}, \mathrm{r}-1)$ の積載量から航路便( $\mathrm{s}, \mathrm{r}-1)$ の陸揚げ量を除き, 航路便(s,r)の船積み量を加えたものに等しい.

$$
\left.\begin{array}{l}
x(s, 1, k)=L(s, 1, k) \quad(\text { for all } s, k) \\
x(s, r, k)=x(s, r-1, k)-U(s, r, k)+L(s, r, k) \\
-\sum_{\sigma\left(s, s^{\prime} r^{\prime}\right)=1} \sum_{k} T R_{k}\left(s r, s^{\prime} r^{\prime}\right)+\sum_{\begin{array}{c}
\sigma\left(s, s^{\prime} r^{\prime}\right)=1 \\
(\text { for all } s, r>1, k)
\end{array}} T R_{k}\left(s^{\prime} r^{\prime}, s r\right)
\end{array}\right\}
$$

ここに, $x(s, r, k)$ : 航路便 $(\mathrm{s}, \mathrm{r})$ の品目 $\mathrm{k}$ の輸送量.

(4)貨物船の積載量に関する条件

航路便 $(\mathrm{s}, \mathrm{r})$ の積載量は, 貨物船 $\mathrm{s}$ の積載容量を上 限とする。

$$
\sum_{k} x(s, r, k) \leqq a(s) \quad(\text { for all } s, r)
$$

ここに, $a(s)$ : 貨物船 $\mathrm{s}$ の積載容量.

\section{(5)運航時刻に関する条件}

航路便 $(\mathrm{s}, \mathrm{r})$ の出港時刻は, 航路便 $(\mathrm{s}, \mathrm{r}-1)$ の出港時 刻に運航時間 $\mathrm{tm}(\mathrm{s}, \mathrm{r}-1)$ と入港待ち時間 $\mathrm{w}(\mathrm{s}, \mathrm{r}-1)$ を加 え, さらに航路便( $\mathrm{s}, \mathrm{r}-1)$ の陸揚げ作業時間と航路便 $(\mathrm{s}, \mathrm{r})$ の船積み作業時間を加えた時刻以降でなければ ならない.この関係を式(6)に示寸. なお, 航路便 $(\mathrm{s}, 1)$ の出港時刻は船積み作業時間のみとなる．また，最 終航路便(s,e)においては，すべての貨物の荷下ろし が終了する時刻は単位輸送期間長 $T$ 以下でなければ ならない.この関係を式(7)に示す.

Tは貨物量の大小を決定するとともに，ある一定 期間に発生した輸送需要をその期間内に輸送するこ とを表現するために設定した時間である.

$$
\left.\begin{array}{l}
t(s, 1) \geqq l(s, 1) \cdot \sum_{k} L(s, 1, k) \quad(\text { for all } s) \\
t(s, r) \geqq t(s, r-1)+t m(s, r-1)+u(s, r-1) \\
+u(s, r-1) \cdot\left\{\sum_{k} U(s, r-1, k)+\sum_{\sigma\left(s, s^{\prime} r^{\prime}\right)=1} \sum_{k} T R_{k}\left(s r-1, s^{\prime} r^{\prime}\right)\right\} \\
+l(s, r) \cdot\left\{\sum_{k} L(s, r, k)+\sum_{\sigma\left(s, s^{\prime} r^{\prime}\right)=1} \sum_{k} T R_{k}\left(s r, s^{\prime} r^{\prime}\right)\right\} \\
\quad \text { (for all } s, r>1)
\end{array}\right\}
$$

$$
\begin{aligned}
& t(s, e)+t m(s, e)+w(s, e) \\
& +u(s, e) \cdot\left\{\sum_{k} U(s, e, k)+\sum_{\sigma\left(s,, s^{\prime}\right)=1} \sum_{k} T R_{k}\left(s r, s^{\prime} r^{\prime}\right)\right\} \leqq T
\end{aligned}
$$

(for all s) (7) 
ここに, $T$ : 単位輸送期間長.

(6)積み替えのための時間調整に関する条件

航路便 $(\mathrm{s}, \mathrm{r})$ から航路便 $\left(\mathrm{s}^{\prime}, \mathrm{r}^{\prime}\right)$ ヘトランシップ輸送 が行われる場合, 航路便( $\left(\mathrm{s}^{\prime}, \mathrm{r}^{\prime}\right)$ の出発時刻は, 航路便 ( $\mathrm{s}, \mathrm{r})$ の出港時刻に, 航路便 $(\mathrm{s}, \mathrm{r})$ の運航時間, 入港待 ち時間と航路便 $(\mathrm{s}, \mathrm{r})$ での陸揚げ作業時間を加えた時 刻以降となる.

ここで, 貨物船 $\mathrm{s}$ が貨物船 $\mathrm{s}$ の到着を待っていた 場合には，貨物船 $\mathrm{s}$ の陸揚げと同時に貨物船 $\mathrm{s}^{\prime}$ の船 積みを始めることができるので, $\left(\mathrm{s}^{\prime}, \mathrm{r}^{\prime}\right)$ の船積み作業 時間は, 式(8)の右辺第 4 項となる. すなわち, 式(8) は(s,r)から (s',r')へのトランシップが可能であるた めの最低条件(必要条件)である.

$$
\begin{aligned}
& t\left(s^{\prime}, r^{\prime}\right) \geqq t(s, r)+t m(s, r)+w(s, r) \\
& +\sum_{\sigma\left(s r, s^{\prime} r^{\prime}\right)=1} u(s, r) \sum_{k} T R_{k}\left(s r, s^{\prime} r^{\prime}\right) \\
& \quad\left(\text { for all } \sigma\left(s r, s^{\prime} r^{\prime}\right)=1\right)
\end{aligned}
$$

\section{（4）港湾容量制限}

上述のモデルによって計算された貨物船の運航が あらかじめ設定した港湾毎の係留可能数の上限を超 過しないよう制限する必要がある。しかし，この制 約条件は線形式として表現することは容易ではない， そこで本研究では, 計算結果が容量を超過した場合 は，その貨物船の入港を単位時間 $(\Delta t)$ だけ遅らせ $(\mathrm{w}(\mathrm{s}, \mathrm{r})=\mathrm{w}(\mathrm{s}, \mathrm{r})+\Delta \mathrm{t})$, それを制約条件の制限值に加 え再計算を行うものとしている.

\section{3. トランシップの内生化}

本研究では，(s,r) から ( $\left.\mathrm{s}^{\prime}, \mathrm{r}^{\prime}\right)$ へのトランシップの 有無を内生的に求める数理モデルについて述べる.

以下では, 従来の港湾間輸送モデルである『基本 モデル』に対して，トランシップ内生化型モデルを 『内生化モデル』と称して両者を区別する.

\section{(1) 定式化}

本研究では，(s,r) から ( $\left.\mathrm{s}^{\prime}, \mathrm{r}^{\prime}\right)$ 一のトランシップの 有無を内生的に求める数理モデルについて述べる.

式(8)は，航路便 (s,r)から（s', r') 一のトランシッ プコンテナがすべて陸揚げされた後でなければ, (s', $\left.\mathrm{r}^{\prime}\right)$ は出航できないことを示している. また, 式(8) は (s', r') が行うトランシップ回数だけ必要であり, それらの中で右辺が最大となる式が真の必要条件と して機能することになる.
さて，ここで，トランシップの有無と制約条件の 㗢きの関係について考える.（s,r) から( $\left.\mathrm{s}^{\prime}, \mathrm{r}^{\prime}\right)$ 一のト ランシップがある(必要な)場合には, $\Sigma_{\mathrm{k}} \mathrm{TR}_{\mathrm{k}}$ $\left(\mathrm{sr}, \mathrm{s}^{\prime} \mathrm{r}^{\prime}\right) \geqq 0$ となり，同時に式(8)が成り立っていな ければならない.一方, トランシップがない(不要な) 場合には $\Sigma_{\mathrm{k}} \mathrm{TR}_{\mathrm{k}}\left(\mathrm{sr}, \mathrm{s}^{\prime} \mathrm{r}^{\prime}\right)=0$ であり，式(8)が成り 立つ必要はない。したがって，こうした関係を同時 に成立させるために，トランシップ量が正值の場合 には式(8)を保存し, トランシップ量が 0 の場合には 式(8)を無力化する方法を考える必要がある. そこで, 式(8)を次式(9)のように修正し，式(10)，式(11)の制 約条件を追加する.

$$
\begin{aligned}
& t\left(s^{\prime}, r^{\prime}\right) \geqq t(s, r)+t m(s, r)+w(s, r) \\
& +\sum_{\sigma\left(s r, s^{\prime} r^{\prime}\right)=1} u(s, r) \sum_{k} T R_{k}\left(s r, s^{\prime} r^{\prime}\right) \\
& +M\left\{\sum_{k} T R_{k}\left(s r, s^{\prime} r^{\prime}\right)-\theta\left(s r, s^{\prime} r^{\prime}\right)\right\} \\
& \sum_{k} T R_{k}\left(s r, s^{\prime} r^{\prime}\right) \leqq \theta\left(s r, s^{\prime} r^{\prime}\right) \\
& \theta\left(s r, s^{\prime} r^{\prime}\right) \geqq \varepsilon
\end{aligned}
$$

ここに, Mは極めて大きな正数, $\varepsilon$ は小さな正数, $\varepsilon \mathrm{M}$ は十分大きな正数であるとする.

式(9)は, 式(8)右辺に第 5 項を追加したものであり， トランシップが正值の場合には第 5 項が 0 となって 式(8)が成立し, トランシップが 0 の場合には第 5 項 が絶対值の大きな負值をとることによって式(8)が 成立しないようにすることを意図したものである.

式(10)，(11)は，式(9)がその機能を果たすことが できるよう $\theta$ (sr,s's')の範囲を限定したものである. 以下，上の 3 式を連立させることによって，上述の 目的を達成できるか考察する．まず，

$$
\begin{aligned}
& \alpha=\sum_{k} T R_{k}\left(s r, s^{\prime} r^{\prime}\right) \\
& \beta=t\left(s^{\prime}, r^{\prime}\right)-t(s, r)-t m(s, r)-w(s, r)-\sum u(s, r) \alpha
\end{aligned}
$$

$$
\text { とおく. }
$$

ここで， $\beta$ は（s,r) が港に到着してからトランシ ップ貨物を下ろし終える時刻と，( $\left.\mathrm{s}^{\prime}, \mathrm{r}^{\prime}\right)$ の出港時刻 との差を表しており, 前者が後者よりも小さければ 正，大きければ負の值をとる.

$\theta$ (sr,s's')を単に $\theta$ と表現すると，式(9)は,

$$
\beta \geqq M\{\alpha-\theta\}
$$

調整变数 $\mathrm{y}_{0}$ を導入して式（9）を等式化すれば,

$$
\beta-\mathrm{y}_{0}=\mathrm{M}\{\alpha-\theta\}
$$

さらに, 調整変数 $\mathrm{y}_{1}$ と $\mathrm{y}_{2}$ を導入して, 式(10) と式 
表一1 可能解の存在条件 $(\alpha=0$ の場合)

\begin{tabular}{|c|}
\hline $\begin{array}{l}\text { (1) } \mathbf{y}_{0}^{\prime}=0 \text { の場合 } \\
\theta=-\beta^{\prime}, \mathbf{y}_{1}=-\beta^{\prime}, \mathbf{y}_{2}=-\beta^{\prime}-\varepsilon \\
\left(\beta^{\prime}<0 \text { かつ } \varepsilon \leqq-\beta^{\prime} \text { のき，可能解 }\right)\end{array}$ \\
\hline $\begin{array}{l}\text { (2) } \mathbf{y}_{1}=0 \text { の場合 } \\
\theta=0, \quad y_{0}^{\prime}=\beta^{\prime}, y_{2}=-\varepsilon\end{array}$ \\
\hline $\begin{array}{l}\text { (3) } \mathrm{y}_{2}=0 \text { の場合 } \\
\theta=\varepsilon, \quad \mathrm{y}_{1}=\varepsilon, \quad \mathrm{y}_{0}^{\prime}=\varepsilon+\beta^{\prime} \\
\left(\beta^{\prime} \geqq 0 \text { のとき, または } \beta^{\prime}<0 \text { かつ } \varepsilon \geqq-\beta^{\prime} \text { のと }\right. \\
\text { き, 可能解 })\end{array}$ \\
\hline
\end{tabular}

（11）を等式化すると,

$$
\begin{gathered}
\alpha-\theta+\mathbf{y}_{1}=0 \\
\theta-y_{2}=\varepsilon
\end{gathered}
$$

が得られる.

さて, $\alpha=\Sigma_{\mathrm{k}} \mathrm{TR}_{\mathrm{k}}\left(\mathrm{sr}, \mathrm{sr}^{\prime}\right)=0$ のとき, 式(9-1)より，

$$
\theta+\beta^{\prime}-y_{0}^{\prime}=0
$$

ここに, $\quad \beta^{\prime}=\beta / \mathrm{M}, \quad \mathrm{y}_{0}^{\prime}=\mathrm{y}_{0} / \mathrm{M}$

したがって， $\alpha=0$ のときには, 式(9-1)，(10-1), 式(11-1)は，それぞれ，

$$
\begin{aligned}
& \theta-y_{0}{ }^{\prime}=-\beta^{\prime} \\
& \theta-y_{1}=0 \\
& \theta-y_{2}=\varepsilon
\end{aligned}
$$

と表すことができる.

これらの 3 式は，制約条件を等式化したものであ るので，可能解が存在するためにはこれらが同時に 成立しなければならない，3つの式の未知数が 5 個 であり解が一意に定まらないので，各未知数を非基 底変数としたときに可能解が存在するかを調べる.

ところで， $\theta$ は式(11)より正值であることが明らか である. また $\beta^{\prime} は$, 複数の決定変数の合成変数であ るため, 非基底変数として取り扱うことができない. そこで, $\mathrm{y}_{0}{ }^{\prime}, \mathrm{y}_{1}, \mathrm{y}_{2}$ の 3 変数を非基底変数の候補と して, 可能解の存在条件を調べたのが表一1である.

ケース(2)では $\mathrm{y}_{2}$ が負となるため可能解は存在し ないが, ケース(1)とケース(3)では， $\beta$ 'と $\varepsilon$ の関係に よっていずれかに可能解が存在する.すなわち， $\beta^{\prime}<0$ かつ $\varepsilon \leqq 一 \beta^{\prime}$ の場合にはケース(1)が可能解を もち, $\beta^{\prime} \geqq 0$ の場合または $\beta^{\prime}<0$ かつ $\varepsilon \geqq-\beta^{\prime}$ の場 合には，ケース(3)が可能解をもつことがわかる．し たがって, $\beta^{\prime}(\beta)$ の正負に関わりなく, 可能解が存 在するといえる.

ここで, 式(9)の右辺第 5 項 $\mathrm{M}(\alpha-\theta)$ は, ケース (1)では $\beta$ 'M (= $\beta)$ となり, 式(9)が $\beta=\beta$ となって

\begin{tabular}{|c|c|}
\hline $\begin{array}{l}\text { (1) } \mathbf{y}_{0}^{\prime}=0 \text { の場合 } \\
\theta=\alpha-\beta^{\prime}, y_{1}=-\beta^{\prime}, y_{2}=\alpha \\
\text { (可能解なし) }\end{array}$ & \\
\hline $\begin{array}{l}\text { (2) } \mathbf{y}_{1}=0 \text { の場合 } \\
\theta=\alpha, \mathbf{y}_{0}^{\prime}=\beta^{\prime}, \mathbf{y}_{2}=\alpha-\varepsilon\end{array}$ & $(\alpha>\varepsilon)$ \\
\hline $\begin{array}{l}\text { (3) } \mathbf{y}_{2}=0 \text { の場合 } \\
\theta=\varepsilon, \mathbf{y}_{1}=\varepsilon-\alpha, \mathbf{y}_{0}^{\prime}=\varepsilon\end{array}$ & $\alpha \quad(\alpha<$ \\
\hline
\end{tabular}
無意味な解であるといえる．また，ケース(3)では $\mathrm{M}(\alpha-\theta)=-\varepsilon \mathrm{M}$ となるが， $\varepsilon \mathrm{M}$ は絶対值が十分 に大きな正の数であることから式(9)の右辺は負と なり，式(9)は無力化される. 以上のように, ケース
表-2 可能解の存在条件 $(\alpha>0$ の場合)

(1)，ケース(3)のいずれの場合も, $\mathrm{t}(\mathrm{s}, \mathrm{r})$ と $\mathrm{t}\left(\mathrm{s}^{\prime}, \mathrm{r}^{\prime}\right)$ の 関係は式(9)によって規定されず，結局 $\alpha=0$ の場合 には，式(9)は無力化されることがわかる.

次に, $\alpha>0$ の場合を考える. 同様に,

$$
\begin{aligned}
& \theta-y_{0}{ }^{\prime}=\alpha-\beta^{\prime} \\
& \theta-y_{1}=\alpha \\
& \theta-y_{2}=\varepsilon
\end{aligned}
$$

と表わされる.

$\alpha>0$ の場合，（s,r) と（ $\left.\mathrm{s}^{\prime}, \mathrm{r}^{\prime}\right)$ の間のトランシッ プが生じるので，式(8)が成立する必要があり， $\beta$ ， $>0$ でなければならない.このことを考慮して，可 能解の存在条件を分析すると表一2が得られる.

$\alpha>0$ の場合は, $\beta^{\prime}>0$ を前提とすると $\mathrm{y}_{1}<0$ と なり, ケース(1)は可能解が存在しない. ケース(2)と (3)は $\alpha>0$ であれば, $\alpha>\varepsilon$ と $\alpha<\varepsilon$ に関わらず可 能解が得られることを示している. そして，ケース (2)では $\theta=\alpha$ なので, 式(9)右辺の第 5 項 $\mathrm{M}(\alpha-\theta)$ は 0 となり, 式(9)は式(8)に一致する.

一方，ケース(3)では， $\alpha<\varepsilon$ の条件下で可能解が 得られるが, この場合，(s,r)から ( $\left.\mathrm{s}^{\prime}, \mathrm{r}^{\prime}\right)$ へのトラン シップが $\varepsilon$ 以下と微小であり, 実質的にはトランシ ップは発生しない.

また，計算結果に対する式(9)による拘束の程度に ついては以下のように考えられる.

ケース(3)では $\theta=\varepsilon$ であるため, 式(9)右辺の第 5 項が $\mathrm{M}(\alpha-\varepsilon)<0$ となる. $\alpha$ が $\varepsilon$ に対して十分に 小さければ, $\mathrm{M}(\alpha-\varepsilon)$ が絶対值の大きな負值をと るため, 式(9)は無力化される. しかし， $\alpha$ と $\varepsilon$ 差 が小さくなるにつれ, $\mathrm{M}(\alpha-\varepsilon)$ が 0 に近づくため, 式(9)は近似的に式(8)とみなされる.すなわち, ケ一 ス(3)ではトランシップ量の大小と式(9)の拘束の強 弱が連動し，連続的に変化する構造であることが理 解できる.

以上の考察のように, トランシップの有無にかか わらず，式(9)，(10)，（11）の連立によって可能解が 得られ，意図した制約条件も機能することがわかる.

\section{(2)内生化モデルの適用例}

これまで述べた内生化モデルに関して, 港湾で 2 
隻の貨物船が相互にコンテナをやり取りする状況と, そのトランシップがお互いに出港時刻に影響を与え る状況を同時に確認することを目的として，4港湾， 2 貨物船, 2 品目の簡単なケースに適用寸る. 本例 では, 図ー3 に示したように, 貨物船 1 は港湾 1 と 2 に寄港でき, 貨物船 2 は港湾 $2 ， 3 ， 4$ に寄港でき ることとした．また，港湾 2 において貨物船 1 と 2 の間で貨物のトランシップが可能であるので, $(1,1)$ $\rightarrow(2,2)$ と $(2,1) \rightarrow(1,2)$ の 2 組の積替え量に関する変 数を導入した. 基本モデルによる計算では, 可能な トランシップすべての有無を組み合わせると 4 回の 計算が必要であるが, 内生化モデルを用いた本法で は，トランシップが効果的な場合のみ，積替え量の 変数が正值をとるため, 1 回の計算で済む.

表一3に港湾の入港料, タグボート使用料, コン テナ取扱い時間, 岸壁使用料を, 表一4に貨物船の 重量, 積載能力, 運航速度, 燃費, 船費を示す. 表 一3の内容は全港湾に共通とした. 本例では, 普通 と大型の 2 つタイプの貨物船を使用した. 各港湾 の品目別輸出入量を表一 5 に示寸. 最適解は表 -6 , 図一3に示すとおりである.

本例の場合には 2 隻の貨物船の間で同時に 2 組の

\begin{tabular}{|c|c|c|c|}
\multicolumn{5}{c}{ 表ー3 港湾使用の費用等 } \\
\hline $\begin{array}{c}\text { 入港料 } \\
\text { (円/ton) }\end{array}$ & $\begin{array}{l}\text { タグボート使 } \\
\text { 用料(円/ton) }\end{array}$ & $\begin{array}{l}\text { コンテナ取扱時 } \\
\text { 間(時間/TEU) }\end{array}$ & $\begin{array}{l}\text { 岸壁使用料間 } \\
\text { (円/時/ton) }\end{array}$ \\
\hline 2.6 & 3.0 & 0.0125 & 0.75 \\
\hline
\end{tabular}

表-4 貨物船のサイズと費用

\begin{tabular}{|c|c|c|c|c|}
\hline $\begin{array}{c}\text { 重量 } \\
\text { (ton) }\end{array}$ & $\begin{array}{c}\text { 積載能力 } \\
\text { (TEU) }\end{array}$ & $\begin{array}{l}\text { 運 航 速 度 } \\
(\mathrm{km})\end{array}$ & $\begin{array}{c}\text { 燃費 } \\
\text { (円 } / \mathrm{km})\end{array}$ & $\begin{array}{l}\text { 船費 } \\
\text { (円/時間) }\end{array}$ \\
\hline 40000 & 300 & 23 & 825 & 146886 \\
\hline 60000 & 500 & 24 & 1203 & 209306 \\
\hline
\end{tabular}

表 -5 輸出入量 (単位:TEU)

\begin{tabular}{|c|r|r|r|r|}
\hline 港湾 & \multicolumn{2}{|c|}{ 品目 1} & \multicolumn{2}{|c|}{ 品目 2} \\
\hline (1) & 150 & 0 & 0 & 50 \\
\hline (2) & 0 & 50 & 0 & 50 \\
\hline (3) & 0 & 50 & 150 & 0 \\
\hline (4) & 0 & 50 & 0 & 50 \\
\hline
\end{tabular}

注) 左 : 輸出量, 右 : 輸入量

表一6 ケース 1 の最適解（単位:TEU）

\begin{tabular}{|c|c|c|c|c|c|}
\hline \multirow{2}{*}{$\begin{array}{l}\text { 航路便とト } \\
\text { ランシップ }\end{array}$} & \multirow{2}{*}{$\begin{array}{l}\text { 出港時刻 } \\
\text { (日) }\end{array}$} & \multicolumn{2}{|c|}{ 品目 1} & \multicolumn{2}{|c|}{ 品目 2} \\
\hline & & 船積 & 陸揚 & 船積 & 陸揚 \\
\hline$(1,1)$ & 1.875 & 150 & 50 & 0 & 0 \\
\hline$(1,2)$ & 6.766 & 0 & 0 & 0 & 50 \\
\hline$(2,1)$ & 1.875 & 0 & 0 & 150 & 50 \\
\hline$(2,2)$ & 6.548 & 0 & 50 & 0 & 50 \\
\hline$(2,3)$ & 9.973 & 0 & 50 & 0 & 0 \\
\hline \multicolumn{2}{|c|}{ トランシップ $(1,1) \rightarrow(2,2)$} & \multicolumn{2}{|c|}{100} & \multicolumn{2}{|c|}{0} \\
\hline \multicolumn{2}{|c|}{ トランシップ $(2,1) \rightarrow(1,2)$} & \multicolumn{2}{|c|}{0} & \multicolumn{2}{|c|}{50} \\
\hline
\end{tabular}

*)上段を普通貨物船，下段を大型貨物船とする.

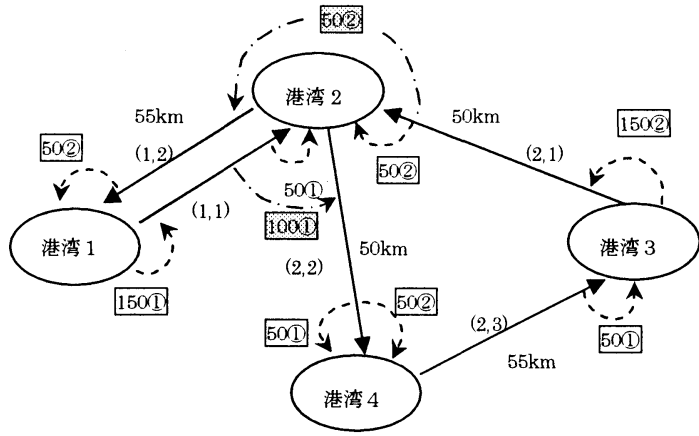

*) 直線の矢印は航路便, 破線矢印は実需給の積み降ろし, 一 点鎖線はトランシップ, 枠囲い内の数字はコンテナ数 (TEU), 丸数字は品目, を表している.

\section{図ー3 港湾配置とコンテナ輸送の計算結果}

トランシップが行われるが，両貨物船ともにすべて の貨物を降ろし終えた後でないと, トランシップ貨 物を積みこめない. すなわち, 航路便 $(1,2)$ では, $6.141(=1.875+55 / 23+150 \times 0.0125)$ 以降に積み込み が開始できる. 一方, 貨物船 2 がトランシップ貨物 を降ろし始めることができる時刻は 4.673 $(=1.875+50 / 23+50 \times 0.0125)$ であるため, 航路便 $(1,2)$ の出港時刻は $6.766(=6.141+50 \times 0.0125)$ 以降 となる. 航路便 $(2,2)$ にいても同様であり, 得られ た最適解は式(8)の制約条件を満たしている.

\section{4. 基本モデルと内生化モデルの計算量の比較}

\section{(1)検討ケース}

基本モデルと内生化モデルの計算量に関する比較 検討を行うため, 4 ケースを用いた.

計算回数は貨物船数と最大寄港数によって定まる ので, ケース設定に当っては, 貨物船数と最大寄港 数を適度に組合せるとともに計算時間を考慮して, 貨物船に関して 2 隻と 3 隻, 最大寄港数に関して 3 と 4 とし，表ー7に示すケース 1 〜ケース 4 を設定 した.ケース 1 は前節で採用したものと同じである.

また，ケース 4 は図ー4に示す港湾配置のもとに 港湾数 6 , 貨物船 3 , 最大寄港数 3 という条件を設 定した. ケース 2,3 では, ケース 4 を基本として港 湾数, 貨物船数, 最大寄港数を変化させた.

\section{(2)解析結果}

表ー7に解析結果を示す. 同表には, 基本モデルに 対する内生化モデルの性能, および基本モデルの計 算回数, 計算時間の絶対値を示した. 


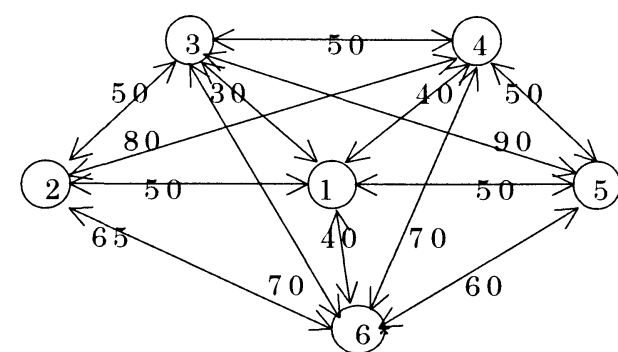

＊）丸数字は港湾番号，その他数字は港湾間距離 $(\mathrm{km})$

図-4 ケース 4 の港湾配置

表ー7 検討ケース別計算結果の比較

\begin{tabular}{|c|r|r|r|r|}
\hline & ケース 1 & ケース 2 & ケース 3 & ケース 4 \\
\hline 港湾数 & 4 & 5 & 5 & 6 \\
貨物船数 & 2 & 2 & 2 & 3 \\
最大奇港数 & 3 & 3 & 4 & 3 \\
\hline 変量数平均の比 & 1.02 & 1.03 & 1.08 & 1.09 \\
条件式数平均の比 & 1.1 & 1.1 & 1.17 & 1.16 \\
LP 計算回数 & 44 & 150 & 42180 & 407878 \\
LP 計算回数の比 & 0.27 & 0.48 & 0.07 & 0.02 \\
計算時間 (秒) & 0.61 & 2.85 & 1182.0 & 38940.0 \\
計算時間の比 & 0.36 & 0.48 & 0.12 & 0.03 \\
\hline
\end{tabular}

内生化モデルでは基本モデルに比べて平均の変量 数，条件式数がともに大きく，ケース 1 では両者の 比（内生化モデル/基本モデル）がそれぞれ 1.02 , 1.1 である. また, 計算回数, 計算時間で両者の比 を取ると，それぞれ $0.27 ， 0.36$ であり，計算量は内 生化モデルの方が小さい.

ケース 2〜ケース 4 へと規模が大きくなるにした がって, 変量数の比は $1.03 \sim 1.09$, 条件式数の比は 1.1〜1.16 の幅で多少増加する変化するものの, 特 に大きな変化はない. これに対し, 計算回数の比は 0.48 0.02, 計算時間の比は $0.48 \sim 0.03$ の幅で大き く減少している. すなわち, 計算の負荷は内生化モ デルを用いることによって大幅に削減でき, 内生化 モデルが計算ケースの大規模化に対応できる可能性 を示唆している．ちなみに，基本モデルを用いたケ

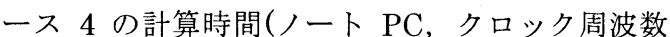
$800 \mathrm{MHz}$ 程度)は，38940sec(約 $10.8 \mathrm{~h}$ )に達してお り, 所要時間の観点からこれ以上の規模の計算は基 本モデルでは実質的に不可能である.

\section{5. 結論と今後の課題}

本研究では, 既往研究で定式化した品目別港湾間 輸送モデルを基本として，トランシップを内生的に 求める内生化モデルの定式化を行い，このモデルに よって基本モデルから得られる最適解のうちの 1 つ
が得られること，および計算時間を大幅に減じるこ とが可能であり，より大規模な事例一の応用が可能 であることを示すことができた.

本研究で対象としたような組合せ最適化問題は, 近年，遺伝的アルゴリズム等の試行錯誤法で短時間 に優秀な近似解を得られることが示され，試行錯誤 法の有効性が実証されつつある。しかし，こうした 方法は，実用的である反面，最適解に達する保証が なく，また，計算過程でどの程度最適解に接近した かも明らかでないなど, 解の選択(計算の打切り)に あいまいさが残る。

こうした観点から，著者は最適解を求めることに 価値をおきつつ計算量を削減する方向で研究を進め て来た. また，一方で組み合わせ最適化問題に試行 錯誤法を援用する場合においても，組み合わせ要素 を削減し計算量を少なくすること，すなわち，モデ ルを軽くすることの意味は大きいと考えられる.

港湾間輸送モデルにおける組合せ要素としては, 本研究で取り扱ったトランシップのほかにも，貨物 船経路の組み合わせがあり，この組み合わせ要素の 削減が課題である. また, 組み合わせ要素の削減と は異なるが，任意時間における港湾容量制限をいか に定式化し線形計画モデルに組み入れるかという課 題もある．今後はこうした課題に取り組む予定であ る.

\section{参考文献}

1）福地信義：リニア駆動搬送台車を用いた高密度集積コ ンテナストックヤードの概念設計, マリーン・エキス プレス構想(Phase-2)に関する調査研究報告(平成 8 年度), pp.11-22, 1997.5.

2）黑田勝彦,楊 賛,竹林幹雄,安東昌輝：フィーダーサー ビスによる国内コンテナ貨物流動分析, 土木計画学 研究・講演集 No19 (2),pp. 203-205, 1996.11.

3）藤野直明,郡司浩太郎,加藤博敏,中崎 剛 : 国際海上二 学研究・講演集 No18(2), pp. 517-520,1995.12.

4) TOI,S. and OHTA,T. : The Introduction Effect of High-density Integrated Stockyard into a Port, Journal of the Eastern Asia Society for Transportation Studies, Vol.3, No.2, September, 1999 , pp.155-165.

5）家田仁,柴崎隆一,内藤智樹：アジア圈国際コンテナ貨 物流動モデルとその配分原理に応じた特性比較, 土木 計画学研究・講演集, No.20(2), pp.101-104, 1997.11.

6）川崎隆広, 外井哲志, 太田俊昭, 山内誉史 : 品目別港湾 間輸送モデルを用いた港湾機能の改善効果に関する 基礎的研究, 土木計画学研究·論文集 17,pp. 729-734, 1999. 9 .

(2002. 9. 30 受付) 


\section{TRANSPORTATION MODEL BETWEEN HARBORS TREATING TRANSSHIP AS INTERNAL VALUABLES}

\section{Satoshi TOI}

Author developed the mathematical model to minimize transportation cost between harbors, using the linear programming. This model enables us to study the change of the transportation cost based on the condition of facilities. But when the scale of the transportation grows, the total combination case becomes rapidly huge, and the calculation becomes impossible substantially. Then, in this research, the internal variables concerning transship combination were introduced and the formulation was attempted to save calculation. Finally the introduction effect was tested through a simple harbor network. 